\title{
Genetic gain in the breeding program of common beans at IAC from 1989 to 2007
}

\author{
Alisson Fernando Chiorato ${ }^{1}$, Sérgio Augusto Morais Carbonell ${ }^{1}$, Roland Vencovsky ${ }^{2}$, Nelson da Silva Fonseca Júnior ${ }^{3}$ and José \\ Baldin Pinheiro ${ }^{2 *}$
}

Received 9 March 2010

Accepted 20 June 2010

\begin{abstract}
The goal of the present work was to evaluate the genetic gain obtained in grain yield for the common bean genotypes from 1989 until 2007, at the Instituto Agronômico de Campinas, in the state of São Paulo. Genetic gain has been separated into two research periods; the first, from 1989 to 1996, and the second, from 1997 to 2007. In the first period, a genetic gain of $1.07 \%$ per year was obtained, whereas for the second period, the gain was zero. However, the mean yield of the evaluated lines was approximately $1000 \mathrm{~kg} \mathrm{ha}^{-1}$ superior to the figures obtained in the first period. The main cause for the absence of genetic gain in the second period is that the focus of the breeding program was changed to grain quality. The individualized analysis of the genotypes with carioca grains in the second period indicated the lack of genetic gain during the investigated period.
\end{abstract}

Key words: Phaseolus vulgaris, selection, assays, adjusted means.

\section{INTRODUCTION}

Brazil is an important producer of Common beans worldwide, although the mean national yield is considered low. Therefore, breeding programs throughout the country aim to select more productive genotypes in order to increase yield thresholds. Crosses between potential parents and nation-wide selection assays are some of the strategies used in the search for cultivars with higher yields.

Besides the strategies mentioned previously, genetic yield gain for a given plant crop depends on the frequent re-evaluation of the genotypes and methodologies employed by the breeding program. Determination of genetic progression estimates is fundamental in decision- making processes concerning the maintenance or implementation of novel selection methodologies in breeding programs (Soares et al. 2005).

Genetic gain estimates for Common bean crops in Brazil range from $0.6 \%$ to $1.90 \%$ a year, representing absolute gains of 14 to $30 \mathrm{~kg} \mathrm{ha}^{-1}$ year $^{-1}$ (Pompeu 1993, Abreu et al. 1994, Matos et al. 2007). The consideration of the breeding method employed is crucial to estimate the genetic progression, since there are methods that directly compare previous cultivars to new ones (Pompeu 1993, Salado Navarro et al. 1993, Bulman et al. 1993, Rodrigues et al. 2007 and Souza et al. 2007) and indirect methods that analyze the experiments conducted by breeding programs as a function of a desired period of time for which the

\footnotetext{
${ }^{1}$ Instituto Agronômico, Centro de Grãos e Fibras, C.P. 28, 13020-902, Campinas, SP, Brazil

${ }^{2}$ Escola Superior de Agricultura Luiz de Queiroz, Departamento de Genética, C.P. 83, 13400-970, Piracicaba, SP, Brazil. *E-mail: baldin@esalq.usp.br

${ }^{3}$ Instituto Agronômico do Paraná, Rodovia Celso Garcia Cid, km 375, Bairro Três Marcos, 86001-970, Londrina, PR, Brazil.
} 
genetic gain is to be determined (Abreu et al. 1994, Breseghello et al. 1999, Matos et al. 2007). The indirect method is based on multi-locality competition assays for cultivars and lines used as reference control-cultivars, which are shared by all experiments during the period of time in consideration. The control-cultivar must be a good representative of the agronomical features of interest to the market, especially when the investigated feature is yield. In the absence of standard control-cultivars, adjusted arithmetical means of the tested treatments can be used to estimate the genetic gain for each year.

The current work aimed to estimate the genetic gain of the breeding program of common beans at the Instituto Agronômico - IAC, from 1989 to 1996 and from 1997 to 2007. The genetic progression for the carioca grain type of beans for the period corresponding to 1997 to 2007 was also determined.

\section{MATERIAL AND METHODS}

The current work was carried out employing data from 134 genotypes developed by the breeding program at the Instituto Agronômico-IAC, located in Campinas, SP. A total of 211 experiments were analyzed in a time period ranging from 1989 to 2007, consisting of data obtained from experiments carried out in 31 regions in the state of São Paulo.
In order to estimate the genetic gain spanning 19 years of research, the period was divided into two research stages. The first stage spans the period from 1989 to 1996, for which 111 genotypes displaying carioca and black tegument were evaluated, and a second stage ranging from 1997 to 2007, where 23 genotypes also exhibiting carioca and black tegument were investigated. For the second research period, an average of four to five advanced lines were evaluated per selection cycle, where each cycle lasted two years in evaluation; thus, comprising a total of 23 genotypes during the 11 years of research in the period of time (Table 1).

From 1989 to 2007, ten selection cycles were carried out, with five cycles carried out from 1989 to 1996, and the remaining five, from 1997 to 2007. During the period from 1989 to 1996, which spans an interval of eight years, five selection cycles were carried out due to the fact that in 1989 and 1994, novel sets of lines, absent from the other years, were evaluated (Table 1). It is noteworthy that considering the 1998 regulations concerning VCU assays (Value for Cultivation and Use), the lines that were evaluated only in 1989 and 1994 are not allowed to be recommended as novel cultivars, since a minimum twoyear period of evaluation is required. The goal of the current work is to estimate genetic gain indices, thus, we have decided to consider the years of 1989 and 1994 as selection cycles. In the period ranging from 1997 to 2007, an

Table 1. List of experiments, sowing seasons and control cultivars used to evaluate 134 lines developed for the growing conditions of common beans in the state of São Paulo from 1989 to 2007

\begin{tabular}{|c|c|c|c|c|}
\hline Selection cyele & $\begin{array}{l}\text { Number of } \\
\text { new genotypes } \\
\text { evaluated }\end{array}$ & Evaluation Season & $\begin{array}{l}\text { Number of } \\
\text { experiments }\end{array}$ & $\begin{array}{l}\text { Control cultivar } \\
\text { employed }\end{array}$ \\
\hline 1989 & 19 & Winter of 1989 & 3 & Carioca $80 \mathrm{SH}$ \\
\hline $1990 / 1991$ & 17 & $\begin{array}{l}\text { Dry season of } 1989 \text { to } \\
\text { dry season of } 1991\end{array}$ & 17 & Carioca $80 \mathrm{SH}$ \\
\hline $1991 / 1992 / 1993$ & 18 & $\begin{array}{l}\text { Winter of } 1991 \text { to winter } \\
\text { of } 1993\end{array}$ & 28 & $\begin{array}{c}\text { Carioca } 80 \text { SH Rosinha } \\
\text { G2 }\end{array}$ \\
\hline 1994 & 18 & Winter of 1994 & 4 & $\begin{array}{l}\text { IAC - Carioca Pyach } \\
\text { Rosinha G2 }\end{array}$ \\
\hline $1995 / 1996$ & 39 & $\begin{array}{l}\text { Dry season of } 1995 \text { to } \\
\text { rainy season of } 1996\end{array}$ & 37 & $\begin{array}{l}\text { IAC - Carioca Pyatã } \\
\text { Rosinha G2 }\end{array}$ \\
\hline $1997 / 1998$ & 5 & $\begin{array}{l}\text { Dry season of } 1997 \text { to } \\
\text { miny season of } 1998\end{array}$ & 24 & $\begin{array}{c}\text { IAC-Carioca IAC - } \\
\text { Una }\end{array}$ \\
\hline $1999 / 2000$ & 4 & $\begin{array}{l}\text { Dry season of } 1999 \text { to } \\
\text { rainy season of } 2000\end{array}$ & 31 & $\begin{array}{c}\text { LAC-Carioca Eve } \\
\text { LAC-Una }\end{array}$ \\
\hline $2001 / 2002$ & 5 & $\begin{array}{l}\text { Dry season of } 2001 \text { to } \\
\text { rainy season of } 2002\end{array}$ & 25 & $\begin{array}{l}\text { LAC - Carioca Eté } \\
\text { LAC - Una }\end{array}$ \\
\hline $2003 / 2004$ & 4 & $\begin{array}{l}\text { Dry season of } 2003 \text { to } \\
\text { rainy season of } 2004\end{array}$ & 15 & $\begin{array}{l}\text { IAC- Carioca Tybata } \\
\text { LAC - Una }\end{array}$ \\
\hline $2005 / 2006 / 2007$ & 5 & $\begin{array}{l}\text { Rainy season of } 2005 \text { to } \\
\text { dry season of } 2007\end{array}$ & 27 & $\begin{array}{l}\text { LAC-Carioca Tybatã } \\
\text { LAC-Una }\end{array}$ \\
\hline 19 years & 134 Genotypes & - & $\begin{array}{c}211 \\
\text { Experiments }\end{array}$ & nes. \\
\hline
\end{tabular}


individualized study for grains exhibiting carioca tegument was carried out. This individual study had not been performed in the previous period, ranging from 1989 to 1996, due to difficulties in identifying the tegument type of some of the lines participating in the experiments.

During the whole period investigated, the genotypes were analyzed throughout three sowing seasons: rainy season ( $1^{\text {st }}$ harvest $)$, dry season $\left(2^{\text {nd }}\right.$ harvest $)$ and winter $\left(3^{\text {rd }}\right.$ harvest) (Table 1). The assays consisted of randomized blocks with four replicates and experimental plots with four lines of 5.0-meter in length, with spacing of 0.50 to 0.60 meters between the lines according to the crop location and using 10 to 12 viable plants per linear meter. The evaluated area for yield consisted in the two central lines.

The estimates of genetic gain were obtained by linear regression analyses from adjusted means of annual average grain yield $\left(\mathrm{kg} \mathrm{ha}^{-1}\right)$ of the genotypes used in the VCU assays. The adjusted means were obtained by joined estimate analyses of the effects of the genotypes, according to the following model:

$Y_{(i j k)}=m+t_{i}+a_{k}+(t a)_{i k}+r_{J(k)}+e_{i j k}$, where, $Y_{(i j k)=}$ observation of the genetic treatment $\mathrm{i}$, in location $\mathrm{k}$ and replicate $j ; m=$ general means, (fixed); $t_{i}=$ effect of treatment $i$, with $i=1,2,3 \ldots I$ (fixed); $a_{k}=$ effect of location $k$, with $k=1,2,3 \ldots K($ random $) ;(t a)_{i k}=$ effect of the interaction between treatment I and location $k$ (random); $r_{j(k)}=$ effect of replication $j$, within location $k=1,2,3 \ldots, K$ (random); and, $e_{i j k}=$ mean environmental error (random).

In order to obtain the adjusted means, the methodology used was based on mixed models, separating fixed from random effects, as indicated by Searle (1987) where $Y=X b$ $+Z U+E$, where $Y$ is the vector of observed data; $X$ is the matrix of incidence of known fixed effects; $b$ is the vector of the parameters of unknown fixed effects; $Z$ is the incidence matrix of known random effects; $U$ is the vector of the parameters of unknown random effects and $E$ is the vector of random errors. The model considers that $U$ and $E$ are not correlated and display a mathematical expectation equal to zero and $G$ and $R$ variances, respectively, as shown:

$$
\operatorname{Var}\left[\begin{array}{l}
U \\
E
\end{array}\right]=\left[\begin{array}{ll}
\mathrm{G} & 0 \\
0 & \mathrm{R}
\end{array}\right] \text {, where }
$$

$G=$ matrix of variances and co-variances of the random effect present in vector $U$ and

$R=$ matrix of residual variances and co-variances.

The matrix $G$ is square, composed by the variation components of the random fractors in the model, diagonally disposed, with the remaining figures equal to zero. Variation components are present in n elements of the $G$ matrix, where $\mathrm{n}$ is the number of levels of the corresponding factor. The matrix R, in turn, is also square with the column and line numbers equal to the number of observations. The matrix is constituted by the variation component of the diagonal experimental error, and the other figures equal to zero.

The variation of $Y$ (observations vector), represented by $V$ matrix, is obtained by the matrix expression:

$$
\operatorname{Var}(Y)=V=Z G Z^{\prime}+R \text { where, }
$$

$Z$ is the known matrix of incidence of random effects;

$G$ is the unkown matrix of the variances and covariances of the randomized effects present in the vector $U$

$Z$ ' is the transposed matrix and

$R$ is the unknown matrix of residual variances and covariances.

In order to obtain estimates of the model parameters, all matrices must consist in variance components ( $G$ and $R$ ). The required variance components were estimated using the Restricted Expectation Maximization Likehood (REML method). The procedure allows the establishment of the equations described in Henderson et al. (1959):

$\left[\begin{array}{llll}X^{\prime} & R^{-1} X & X^{\prime} & R^{-1} Z \\ Z^{\prime} & R^{-1} X & X^{\prime} & R^{-1} Z+G^{-1}\end{array}\right]\left[\begin{array}{l}\beta \\ U\end{array}\right]=\left[\begin{array}{lll}X^{\prime} & R^{-1} & Y \\ Z^{\prime} & R^{-1} & Y\end{array}\right]$,

The results of these equations correspond to the estimates of the fixed $(\beta)$ and random $(U)$ effects in the model:

$$
\begin{aligned}
& \hat{\beta}=\left(X^{\prime} V^{-1} X\right)^{-1} X^{\prime} V^{-1} Y \\
& \hat{U}=\left(G Z^{\prime} V^{-1} r\right) \\
& r=Y-X \beta
\end{aligned}
$$

According to the model proposed by Henderson et al. (1959), $\beta$ is the Best Linear Unbiased Estimator (BLUEBest Linear Unbiased Estimator), that is, the estimate of the fixed effects in the mixed model; and $U$, corresponds to the best linear unbiased predictor (BLUP- Best Linear Unbiased Predictor) for random factors in the model. In the current work, genetic treatments were considered fixed, focusing the attention on BLUE estimators of the treatments. Once the BLUEs were obtained, the adjusted means were calculated by adding the BLUEs to the constant (m) from the mixed model. The estimates of the parameters 
in the model were obtained by the software SAS (SAS 2001), employing the PROC MIXED routine.

The annual arithmetic means of the genotypes under testing and of the control cultivars were calculated from the adjusted means and subsequently submitted to the linear regression analysis to estimate the genetic progress. Regression analyses were performed using the software SAS, employing the PROC REG routine. The results for absolute gains obtained from the regression analysis are exhibited as $\mathrm{kg} \mathrm{ha}^{-1}$ per final selection cycle. In order to estimate the relative genetic progress, shown as percentage, the following equation was used:

$$
\text { Relative gain } \%=\text { where: } \frac{b}{a} \cdot 100
$$

$b=$ regression coefficient estimating yearly gains obtained by regression analysis;

$a=$ initial estimated yield calculated as the interception of the regression line in the first year (zero).

In order to calculate the gain as percentage per year, the percentage gain for each selection cycle was divided by the average number of years per selection cycle, which was of 1.6 years for the first period and of 2.2 for the second period.

Genetic gains for the periods comprised from 1989 to 1996 and from 1997 to 2007 and the genetic gain for carioca tegument grains were obtained employing the previously described formula. The significance of the linear regression analysis was tested by the F-test using the mean square of the regression against the mean square of the regression deviations, calculated for both periods tested.

The calculations of the genetic gain estimates represented as percentages, as shown in the previous equation, have employed the linear interception point from the regression analysis. It is important to provide details on these calculations, since methods that estimate genetic progress using original experimental data usually employ the cultivars mean in the first year, which causes the method to be dependent on the genotypes yield potential in the first year. In contrast, for those methods using pondered yield results, the genetic gain is influenced by the performance of the control cultivars since the gain is calculated by the general mean pondered as a function of the cultivars employed as a control. Regression methods, especially those using fitted means, provide the closest estimates of the mean for the original hypothetical population, which has never undergone selection cycles, mainly due to the fact that the linear coefficient (a) refers to the value predicted by the linear regression for novel genotypes at the initial evaluation year (zero).

\section{RESULTS AND DISCUSSION}

Genetic gain results were distinct in the comparison between both research periods investigated. The values of the absolute and relative genetic gain, in $\mathrm{kg} \mathrm{ha}^{-1}$ and percentage, respectively, for both periods, are shown in Table 2. It is noteworthy that the results obtained by the employed methodology refer to the genetic gain obtained during each selection cycle, which were, subsequently, transformed to $\mathrm{kg} \mathrm{ha}^{-1}$ year $^{-1}$.

For the period comprised between 1989 and 1996, the linear regression analyses allowed the estimation of an absolute genetic gain of $21.04 \mathrm{~kg} \mathrm{ha}^{-1}$ per selection cycle, which is statistically significant; and a mean annual yield of $1231.5 \mathrm{~kg} \mathrm{ha}^{-1}$ (Table 2). In percentage, a relative genetic gain of $1.71 \%$ per selection cycle and a relative progression of $1.07 \%$ per year were observed. For the period from 1997 to 2007, the calculated genetic gain was negative, with an absolute value of $12.27 \mathrm{~kg} \mathrm{ha}^{-1}$ per selection cycle, statistically non significant. When represented as a percentage, the genetic progression was equivalent to a negative value of $-0.55 \%$ per selection cycle, corresponding to a negative progression of $-0.25 \%$ per year. In contrast, the mean yield for the period was approximately $1000 \mathrm{~kg}$ $\mathrm{ha}^{-1}$ higher in comparison to the yield in the previous period investigated $\left(2234.9 \mathrm{~kg} \mathrm{ha}^{-1}\right)$. It is due to the use of a smaller number of genotypes, all of which displaying high productive potential. The results obtained for the period from 1997 to 2007 may be seen as a warning to the breeding program at IAC, although a negative progression is not represented, they indicate a possible stabilization in genetic yield gain (zero gain), since all the results were statically non-significant (Table 2).

The most important difference between both periods is the method by which the lines were evaluated. This division is due to the fact that during the first period, between 1989 and 1996, experiments consisting of a larger number of lines were used, and since not all evaluated lines exhibited high yields, the average yield during the period was lower in comparison to the period comprising the years between 1997 and 2007. Therefore, it was necessary to analyze both periods separately in order to calculate the genetic gains. In the period ranging from 1997 to 2007, the final evaluation assays were carried out employing a smaller number of lines that displayed higher yield potential. grain 
Table 2. Estimates and standard errors for the mean genetic gains in yield for common bean genotypes, shown as $\mathrm{kg} \mathrm{ha}^{-1}$ and percentage, and details obtained by the use of a method employing linear regression with adjusted means, as a function of the individualized analyses of two research periods conducted by the breeding program at IAC between 1989 and 2007

\begin{tabular}{|c|c|c|}
\hline \multirow{2}{*}{ Estimates and Detalls } & \multicolumn{2}{|c|}{ Research periods from 1989 to 2007} \\
\hline & $1989-1996$ & $1997-2007$ \\
\hline Atroolute gain (kg har' selection cycke') & $21,04^{*}$ & -12.27 \\
\hline Relative gain selection cycle' (\%) & 1.71 & -0.55 \\
\hline Relative gain year ${ }^{-1}(\%)$ & 1.07 & -0.25 \\
\hline Gain standurd error $\left(\mathrm{kg} \mathrm{ha}^{-1}\right)$ & 9.12 & 5.02 \\
\hline Gain standand error (\%) & 0.74 & 0.22 \\
\hline Mean $\left(\mathrm{gg} \mathrm{h}^{-1}\right)$ & 1231.90 & 2234.9 \\
\hline Number of genotypes & III & 23 \\
\hline Number of experiments & 89 & 122 \\
\hline Number of years & 8 & 11 \\
\hline Selectica cycles & 5 & 5 \\
\hline $\mathbf{R}^{2}$ & 0.64 & 0.67 \\
\hline Mean square joined ence & 69260 & 147041 \\
\hline Degrees of froedcen joined error & 7152 & 1927 \\
\hline Joined regressice coefficient (\%) & 19.93 & 17.15 \\
\hline Mean square linear regression & 11871.80 & 6018.75 \\
\hline Mean square deviation linear regression (Mean) & \multicolumn{2}{|c|}{1619.03} \\
\hline Degrees of freedom deviation linear regressice (Mem) & \multicolumn{2}{|c|}{6} \\
\hline Linear Regression F-vest & $7.33^{*}$ & 3.72 \\
\hline
\end{tabular}

Another important factor, making the differences between both investigated periods evident, consists in the policy enforced from the year 1998 on, represented by regulation 298 SDR/MAPA, which establishes evaluation rules for VCU assays. The enforcement of the mentioned policy and the methodologies used for VCU assays at IAC were modified and the novel evaluation method allowed the identification of high-yielding genotypes, which also contributed to the enhanced average yield of these experiments in comparison to the average from the period ranging from 1989 to 1996.

The calculated genetic gain for the initial period (1989 to 1997) was similar to the results obtained by other authors for the same research period; Pompeu (1993) showed a gain of $1.3 \%$ per year, Abreu et al. (1994) calculated a gain of $1.8 \%$ per year and Matos et al. (2007) a gain of $0.6 \%$ per year.

For the period spanning the years between 1997 and 2007, a possible stabilization in the genetic gain for yield was expected due to the changes undergone by the breeding program from the year of 1997 on. Before that year, the main goal of the program was the development of highyielding cultivars exhibiting genetic resistance to Colletotrichum lindemuthianum, the causal agent of anthracnose. After the release of the Carioca cultivar in the 70 s, the packaging industry started working with grains of higher quality to satisfy consumer demands. Thus, with the release, by Embrapa in 1998, of the Pérola cultivar that displays bigger seeds ( $27 \mathrm{~g}$ mean weight of one hundred seeds) in comparison to the Carioca cultivar ( $22 \mathrm{~g}$ mean weight of one hundred seeds), the packaging industry and the consumers preferences were switched towards beans with grains similar to Pérola. In this context, the main goal of the breeding program at IAC, that was to develop anthracnose-resistant cultivars with high yields, did not follow the market trend for grain quality and it rapidly decreased in importance.

From 1997, a work reconciling the advanced lines exhibiting anthracnose resistance to increased technological characteristic traits, such as grain size, grain-darkening resistance, reduced cooking time, percentage of wholegrains after cooking, total solids in the cooking broth and volumetric expansion, was initiated. This change in the goals of the breeding program at IAC from 1997 to 2007 certainly caused the stabilization in genetic gains for yield (zero gain), as shown in Table 2, since the parents employed in crosses aiming to improve grain technological quality exhibited inferior yield potential in comparison to the cultivars recommended to the growers.

The individualized estimates of the yield genetic gain for the Carioca-type of grain uncovered important results for the period comprised between 1997 a 2007 (Table 3). The main underlying reason for the choice of this specific 
AF Chiorato et al.

Table 3. Estimates and standard errors for the mean genetic gains in yield for common bean genotypes, shown as $\mathrm{kg} \mathrm{ha}^{-1}$ and percentage, and details obtained by the use of a method employing linear regression with adjusted means, as a function of the individualized analyses for the tegument type of two research periods conducted by the breeding program at IAC between 1989 and 2007

\begin{tabular}{|c|c|}
\hline \multirow{2}{*}{ Estimates and Details } & $\begin{array}{l}\text { Analysis for Carioca Tegument } \\
\text { Type from } 1997 \text { to } 2007\end{array}$ \\
\hline & Carioca \\
\hline Absolute gain ( $\mathrm{kg} \mathrm{ha}^{-1}$ selection cycle $\left.{ }^{-1}\right)$ & -2.71 \\
\hline Relative gain selection cycle ${ }^{-1}(\%)$ & -0.12 \\
\hline Relative gain year ${ }^{1}(\%)$ & -0.05 \\
\hline Gain standard error $\left(\mathrm{kg} \mathrm{ha}^{-1}\right)$ & 7.52 \\
\hline Gain standard error (\%) & 0.34 \\
\hline Mean $\left(\mathrm{kg} \mathrm{ha}^{-1}\right)$ & 2238.56 \\
\hline Number of genotypes & 18 \\
\hline Number of experiments & 122 \\
\hline Number of years & 11 \\
\hline Selection cycles & 5 \\
\hline $\mathrm{R}^{2}$ & 0.89 \\
\hline Mean square joined error & 149935 \\
\hline Degrees of freedom joined error & 1362 \\
\hline Joined regression coefficient $(\%)$ & 17.29 \\
\hline Mean square linear regression & 294.32 \\
\hline Mean square deviation linear regression (Mean) & 4276.42 \\
\hline Degrees of freedom deviation linear regression (Mean) & 3 \\
\hline Linear regression F-test & 0.07 \\
\hline
\end{tabular}

type for individual analysis is the importance of this type of tegument to the Brazilian market. The Common beans breeding program at IAC focuses the research in materials with a Carioca type of tegument. The calculated genetic gain for yield in carioca-tegument beans was negative, with an absolute value of $-2.71 \mathrm{~kg} \mathrm{ha}^{-1}$ per evaluation cycle, which is equivalent to a relative progression of $-0.12 \%$ per evaluation cycle, and also to a negative yearly progression of $-0.05 \%$ per year, representing the stabilization of the genetic gain in yield, as displayed by the figures close to zero and statistically non-significant. The relative standard deviation for the carioca type, exhibiting a value of $0.34 \%$ per selection cycle, is also an important result that emphasizes the stability of the genetic gain for the carioca type. The results may even be considered positive, since the parameters were statistically non-significant.

These results are summarized in Table 4, showing that the last evaluation cycle (2005/2006/2007) exhibited an average yield for the new genotypes higher than the values obtained for the standard control cultivars used in the experiments. These observations prove that it is feasible to have genetic gain in yield following the strategies used by the Common beans breeding program at IAC to increase technological quality (Table 4).
The detailed yield indices obtained during the five cycles of evaluation carried out from 1997 to 2007 are displayed in Figure 1. It is possible to notice that from the period $1997 / 1998$ to the following cycle in $1999 / 2000$, a decrease in the average yield of the lines occurred and that the trait has regained a slight increase in the cycles of $2003 / 2004$ to $2005 / 2007$. The importance of these results lies in the fact that they confirm that the mean yield potential of the lines is increasing, indicating that the breeding program has not reached a plateau for yield gains, although the period from 1997 to 2007 exhibited null genetic gains for yield.

According to the results obtained for the genetic progression in yield in the period from 1997 to 2007, especially for the carioca type of grains (gain zero), it is observed that yield gains from previous cycles can be resumed by the introduction of novel genotypes exhibiting the additional advantage of better grain quality. The technological quality of the grains has been extremely increased in the latest lines developed by IAC, as shown by the work of Perina et al. (2010).

Currently, higher yield is one of the several traits aimed by Common bean breeding programs. In the current market conditions, high-yield lines will not be accepted 
Table 4. Mean of the new genotypes (MGN), mean of the control cultivars (MTE) and estimates of the genetic gain from adjusted means (GG) for the trait grain yield of common bean genotypes with carioca type of tegument in experiments carried out from 1997 to 2007

\begin{tabular}{cccr} 
Selection & MGN & $\begin{array}{c}\text { MTE } \\
(\mathbf{k g ~ h a}\end{array}$ & GG \\
\cline { 2 - 4 } Periods & (A) & $(B)$ & $(A-B)$ \\
\hline $1997 / 1998$ & 2320.1 & 2241.1 & 79.0 \\
$1999 / 2000$ & 2220.2 & 2336.8 & -116.6 \\
$2001 / 2002$ & 2222.7 & 2336.8 & -114.1 \\
$2003 / 2004$ & 2247.6 & 2272.4 & -24.8 \\
$2005 / 2006 / 2007$ & 2279.2 & 2272.4 & 6.8 \\
\hline
\end{tabular}

by the growers unless they also display other traits important for the producers; such as, grain quality, resistance to at least one important pathogen, erect plant architecture suitable for mechanical harvesters and stability in the production.

Therefore, considerations on the observed stabilization in the genetic gain for yield in the second period of research must take into consideration that this trend was only observed for one trait, yield; and that significant advances in grain technological quality and anthracnose resistance were obtained by the current breeding program, as seen in the works by Perina et al. (2010) and Carbonell et al. (2005). The registration of the cultivar 'IAC Alvorada' (Carbonell et al. 2008), recommended to the growers in December of 2007, is an example of the contribution of the breeding program at IAC to the common beans technological quality. The cultivar exhibits high-resistance to grain

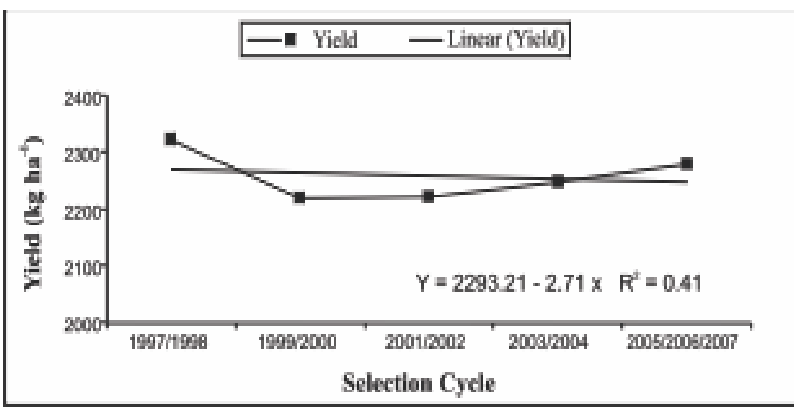

Figure 1. Genetic gain of the common bean genotypes with carioca type of tegument estimated by linear regression analysis using adjusted means, in experiments carried out in the period from 1997 to 2007 by the breeding program of IAC for the state of São Paulo.

darkening and anthracnose, a hundred-seed weight of approximately $30 \mathrm{~g}$, round and uniform-colored grains and an average cooking time of approximately 23 minutes, evaluated by MATTSON cooker (Proctor and Watts 1987). The cultivar represented a great advance, so that the novel genetic bases will allow the program to obtain high-yielding cultivars with excellent grain quality, also providing inputs for other breeding programs by means of crosses using lines or cultivars developed by IAC.

\section{CONCLUSION}

In the period ranging from 1989 to 1996 , a relative genetic gain for a yield of $1.07 \%$ per year was obtained; whereas in the period ranging from 1997 to 2007, the estimate of genetic progression was null, but exhibited a mean genetic yield approximately $1000 \mathrm{~kg} \mathrm{ha}^{-1}$ superior to that of the first period.

\section{Progresso genético no programa de melhoramento de feijoeiro do IAC entre 1989 e 2007}

RESUMO - O objetivo do presente trabalho foi avaliar o progresso genético obtido para a produtividade de grãos de genótipos de feijoeiro entre os anos de 1989 a 2007 no Estado de São Paulo. O progresso genético foi desmembrado em periodos de pesquisa de 1989 a 1996 (primeiro periodo) e de 1997 a 2007 (segundo periodo). No primeiro periodo foi obtido um progresso genético relativo de 1,07\% por ano, enquanto que para o segundo periodo, a estimativa de ganho genético foi igual a zero, mas com produtividade média das linhagens em torno de $1000 \mathrm{~kg} \mathrm{ha}^{-1}$ superior ao primeiro periodo. Foi possivel constatar que a principal causa da ausência de progresso genético no segundo periodo ocorreu após o início dos trabalhos de melhoramento genético para o desenvolvimento de linhagens com melhor qualidade de grãos. A análise separada para genótipos com grão carioca também indicou ausência de ganho genético para o periodo analisado.

Palavras-chave: Phaseolus vulgaris, seleção, ensaios de VCU, médias ajustadas. 
AF Chiorato et al.

\section{REFERENCES}

Abreu AFB, Ramalho MAP, Santos JB and Martins LA (1994) Progresso do melhoramento genético do feijoeiro nas décadas de setenta e oitenta nas regiões sul e alto Paranaíba em Minas Gerais. Pesquisa Agropecuária Brasileira 29: 105-112.

Breseghello F, Rangel PHN and Morais OP (1999) Ganho de produtividade pelo melhoramento genético do arroz irrigado no Nordeste do Brasil. Pesquisa Agropecuária Brasileira 34: 399407.

Bulman P, Mather DE and Smith DL (1993) Genetic improvement of spring barley cultivars grown in eastern Canada form 1910 a 1988. Euphytica 71: 35-48.

Carbonell SAM, Chiorato AF, Ito MF, Perina EF, Gonçalves JGR, Souza OS, Gallo PB, Ticelli M, Colombo CA, Azevedo Filho JÁ (2008) IAC Alvorada and IAC Diplomata - New common bean cultivars. Crop Breeding and Applied Biotechnology 8: 163 166.

Carbonell SAM, Ito MF, Chiorato AF and Moura RR (2005) Avaliação do germoplasma de feijoeiro do IAC quanto à resistência a três raças de Colletotrichum lindemuthianum. Summa Phytopathologica 31: 41-45.

Henderson CR, Kempthorne O, Searle SR and Krosigk CM (1959) The estimation of environmental and genetic trends from records subject to culling. Biometrics 15: 192-218.

Matos JW, Ramalho MAP and Abreu AFB (2007) Trinta e dois anos do programa de melhoramento do feijoeiro comum em minas Gerais. Ciência e Agrotecnologia 31: 1749-1754.

Perina EF, Carvalho CRL, Chiorato AF, Gonçalves JGR and Carbonell SAM (2010) Qualidade tecnológica de grãos de feijoeiro (Phaseolus vulgaris) cultivados em diferentes ambientes. Ciência e Agrotecnologia 34: 398-406.
Pompeu AS (1993) Feijão. In Furlani AMC and Viégas GP (eds.) O melhoramento genético de plantas no Instituto Agronômico. Instituto Agronômico, Campinas, p.111-156.

Proctor JR and Watts BM (1987) Development of a modified Mattson bean Cooker cooker produre based on sensory panel cookability evaluation. Canadian Institute of Food Science and Tecnology 20: 9-14.

Rodrigues O, Lhamby JCB, Didonet AD and Marchese JA (2007) Cinquenta anos de melhoramento de trigo no Sul do Brasil: melhoramento na produção e mudanças associadas. Pesquisa Agropecuária Brasileira 42: 817-825.

Salado-Navarro LR, Sinclair TR and Hinson K (1993) Changes in yeld and seed growth traits in soybean cultivars released in the Southern USA from 1945 to 1983 . Crop Science 33: 1204 1209 .

SAS - Statistical Analysis Sistem (2001) SAS/STAT user's guide. SAS Institute, Cary, 1028p.

Searle SR (1987) Mixed models: a thumbnail survey. In Searle SR (ed.) Linear models for unbalanced data. John Wiley \& Sons, New York, p. 484-519.

Soares PC, Melo PGS, Melo LC and Soares AA (2005) Genetic gain in improvement program of irrigated rice in Minas Gerais. Crop Breeding and Applied Biotechnology 5: 142-148.

Souza MA, Morais OP, Herán REC, Cargnin A and Pimentel AJB (2007) Progresso genético do melhoramento de arroz de terras altas no período de 1950 a 2001. Pesquisa Agropecuária Brasileira 42: $371-376$ 